www.jmscr.igmpublication.org

Impact Factor 6.379

Index Copernicus Value: 71.58

ISSN (e)-2347-176x ISSN (p) 2455-0450

crossref DOI: _https://dx.doi.org/10.18535/jmscr/v6i3.198

Journal Of Medical Science And Clinical Research

\title{
Mean Platelet Volume and its outcome in severe sepsis- A hospital based study
}

Authors

\author{
Rahul P N $\mathbf{N}^{1}$, Anita S P \\ ${ }^{1}$ Junior Resident, ${ }^{2}$ Additional Professor \\ Department of General Medicine, Govt.T D Medical College, Alappuzha, Kerala, India \\ *Correspondence Author
}

\section{Rahul P N}

Junior Resident, Department of General Medicine, Govt.T D Medical College, Alappuzha, Kerala, India Email: rahulpnarayan@gmail.com

\section{Abstract}

Background: Sepsis is defined as the presence (probable or documented) of infection together with systemic manifestations of infection. Severe sepsis is defined as sepsis plus sepsis-induced organ dysfunction or tissue hypo-perfusion. Mean platelet volume (MPV) is a machine-calculated measurement of the average size of platelets found in blood and is typically included in blood tests as part of the CBC. It is considered as an indirect marker for acute thrombocytopenia. This study aims to look at the response of Mean Platelet Volume in severe sepsis and its capability in prognostication with an initial value.

Objective: To assess the association between Mean Platelet Volume (MPV) on Day 1 of ICU admission and the outcome in patients with Severe Sepsis admitted in Medical ICU of Govt. T D Medical College, Alappuzha

Materials and Methods: It is a prospective observational study of 1 year duration. All patients with severe sepsis admitted in Medical ICU of Govt. T D Medical College, Alappuzha during the study period, who met the inclusion and exclusion criteria were taken as study subjects. Patients were divided according to their outcome into Expired and Shift out category of equal numbers. The total sample size of the study is 300. Data obtained were analyzed using SPSS 20.

Results: Out of 300 patients who were selected after passing through the inclusion and exclusion criteria, 195 were male and 105 female patients. The most common reason for admission was Pneumonia (110 patients) followed by Leptospirosis (70 patients). There was no significant difference in the gender and mean age between Expired and Shift out category. There was a significant difference in MPV Day 1 between Expired and Shift out groups with a $t$ value of 3.92 and a $p<0.01$. Also there was a significant difference in Highest MPV between Expired and Shift out groups with a $t$ value of 4.37 and a $p<0.01$. The MPV day 1 and Highest MPV were significantly higher in Expired group compared to Shift out group.

Conclusion: Mean Platelet Volume, which is a part and parcel of a Complete Blood Count, is a hidden gem in our diagnostic panel which can help us to identify a patient with a possibly poor outcome on admission. A 
high MPV on admission to the ICU with severe Sepsis, suggests a higher chance of mortality during ICU stay.

Key words: Severe sepsis; Mean Platelet Volume (MPV); Platelets; Thrombocytopenia; Expired, Shift out.

\section{Introduction}

Humans mount both local and systemic responses to microbes that traverse their epithelial barriers and enter underlying tissues. Fever or hypothermia, leukocytosis or leukopenia, tachypnea, and tachycardia are cardinal signs of the systemic response.

Sepsis is defined as the presence (probable or documented) of infection together with systemic manifestations of infection. Severe sepsis is defined as sepsis plus sepsis-induced organ dysfunction or tissue hypo-perfusion.

The incidence of severe sepsis and septic shock has increased over the past 30 years. Approximately two-thirds of the cases occur in patients with significant underlying illness. Sepsis-related incidence and mortality rates increase with age and pre-existing comorbidity.

Mean platelet volume (MPV) is a machinecalculated measurement of the average size of platelets found in blood and is typically included in blood tests as part of the CBC.

It is considered as an indirect marker for acute thrombocytopenia. Acute thrombocytopenia (whatever the cause), in the setting of an intact marrow function, results in increased thrombopoeisis and large platelets.

Normal range of MPV is 7.5-11.5 fL.

Recent studies have brought to light the response of various Blood Indices in Severe Sepsis. Research has been done into the response of Red Blood Cells and Platelets to an episode of severe sepsis. While multiple studies have looked at the efficacy of Red Cell Distribution Width (RDW) in severe sepsis, it has not been found to accurately predict the outcome in these patients. Conflicting reports have surfaced regarding the usefulness of Mean Platelet Volume (MPV) as a prognostic marker in severe sepsis.

This study aims to look at the response of Mean Platelet Volume in severe sepsis and its capability in prognostication with an initial value.
This study will help us to determine whether an initial value of MPV will tell us the likely outcome of a patient in severe sepsis?

MPV was chosen as no extra cost is required in testing for this entity. It is routinely done as a part of the Complete Blood Count panel which is regularly sent for patients with severe sepsis. This, therefore, is an added bonus since affordability would not limit this study.

\section{Objectives}

The primary objective was to assess the association between Mean Platelet Volume (MPV) on Day 1 of ICU admission and the outcome in patients with Severe Sepsis admitted in Medical ICU of Govt. T D Medical College, Alappuzha.

The secondary objective was to assess the association between Highest MPV during ICU stay and the outcome.

\section{Materials And Methods}

This was a Prospective observational study of one year duration conducted in the Medical ICU of Govt. T D Medical College, Alappuzha.The sample size of this study was 300 .

The inclusion criteria were patients identified as cases of Severe Sepsis as per the guidelines provided by the Society of Critical Care Medicine's latest recommendations, patients above the age of 18 years and patients (or relatives if the patient is not in a condition to give consent) consenting to take part in study.

The exclusion criteria were known or suspected cases of hematological malignancies or other primary marrow disorders, immune thrombocytopenic purpura (ITP), platelet structural and functional disorders and those on chemotherapy. The study variables included age, sex, diagnosis, mean platelet volume and outcome. The outcome was taken as either death of the patient (referred to as 'expired') or the 
patient being shifted out to the ward (referred to as 'shifted to the ward'). Patients admitted into the Medical ICU who satisfy inclusion and exclusion criteria were taken as study subjects. Written consent was be obtained from all patients (or relatives if the patient is not in a condition to give consent) participating in the study. Patients included in the study were evaluated with detailed history, clinical examination, investigations as per the proforma. Their details and lab results were recorded. Clinical details of the patient were followed upto the occurrence of outcome (Expired or Shifted out to the ward). Patients were divided in to 2 groups of equal numbers according to their out come.

Data entered in Microsoft Excel and analysed using SPSS software. Quantitative variables are expressed in mean with standard deviation. Qualitative variables are expressed as proportions or percentages. The statistical techniques used for analysis include mean, standard deviation and test of significance in difference. in the study. Patients included in the study were evaluated with detailed history, clinical examination, investigations as per the proforma. Their details and lab results were recorded. Clinical details of the patient were followed upto the occurrence of outcome (Expired or Shifted out to the ward). Patients were divided in to 2 groups of equal numbers according to their out come.

\section{Results}

Table 1: Demographic details of patients

\begin{tabular}{|l|l|r|}
\hline Sex & Count & N \% \\
\hline Male & 195 & $65.0 \%$ \\
\hline Female & 105 & $35.0 \%$ \\
\hline
\end{tabular}

Among this study $65 \%$ are male patients and $35 \%$ are female patients. The same has been represented below

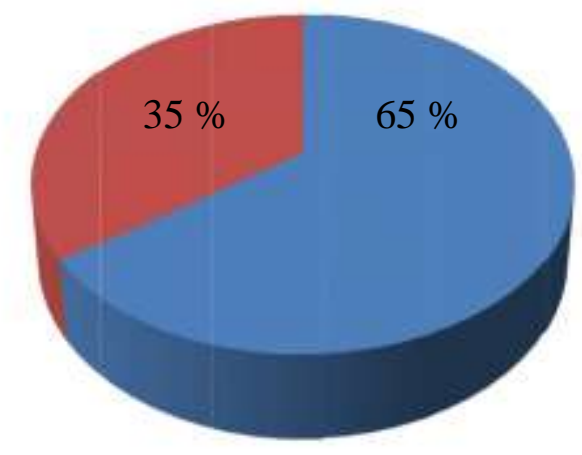

- Male $\square$ Female

Figure 1: Demographic details of patients

Table 2: Group statistics of Shift out patients

\begin{tabular}{|c|c|c|c|c|c|}
\hline & SEX & N & Mean & $\begin{array}{c}\text { Std. } \\
\text { Deviation }\end{array}$ & T \\
\hline $\begin{array}{c}\text { MPV } \\
\text { Day 1 }\end{array}$ & Male & 100 & 7.663000 & 1.2695341 & 0.636 \\
\hline & Female & 50 & 7.975000 & 1.2612274 & $\mathrm{p}>0.05$ \\
\hline
\end{tabular}

Table shows that the $\mathrm{t}$ value is not significant $0.636, p>0.05$; that means gender is not an influencing factor on the Shift out patients' MPV value

Table 3: Group statistics of Expired patients

\begin{tabular}{|c|c|c|c|c|c|}
\hline & SEX & N & Mean & $\begin{array}{c}\text { Std. } \\
\text { Deviation }\end{array}$ & T \\
\hline $\begin{array}{c}\text { MPV } \\
\text { Day 1 }\end{array}$ & Male & 95 & 9.120000 & 1.6108624 & 0.358 \\
\hline & Female & 55 & 9.334545 & 1.5291394 & $\mathrm{p}>0.05$ \\
\hline
\end{tabular}

Table shows that the $\mathrm{t}$ value is not significant $0.358, \mathrm{p}>0.05$; that means gender is not an influencing factor on the Expired patients MPV values 
Table 4: Outcomes and Diagnosis

\begin{tabular}{|c|c|c|c|}
\hline \multirow{2}{*}{ Diagnosis } & \multicolumn{2}{|c|}{ Outcome } & \multirow{2}{*}{ Total } \\
\cline { 2 - 3 } & Shiftout & Expired & \\
\hline Cellulitis & 5 & 5 & 10 \\
\hline Dengue Fever & 5 & 0 & 5 \\
\hline Gluteal Abscess & 5 & 0 & 5 \\
\hline Klebsiella Septicemia & 0 & 5 & 5 \\
\hline Leptospirosis & 40 & 30 & 70 \\
\hline Pneumonia & 35 & 40 & 75 \\
\hline Pneumonia, ACS & 0 & 5 & 5 \\
\hline Pneumonia, UTI & 5 & 10 & 15 \\
\hline Pneumonia, UTI, ACS & 0 & 5 & 5 \\
\hline Prostatitis & 5 & 0 & 5 \\
\hline Puerperal Sepsis & 5 & 0 & 5 \\
\hline Pyelonephritis & 5 & 0 & 5 \\
\hline Snake Bite & 0 & 5 & 5 \\
\hline SBP & 5 & 10 & 15 \\
\hline Staph Septicemia & 5 & 0 & 5 \\
\hline UTI & 30 & 15 & 45 \\
\hline UTI, ACS & 0 & 5 & 5 \\
\hline UTI, Pneumonia & 0 & 10 & 10 \\
\hline UTI, Pyelonephritis & 0 & 5 & 5 \\
\hline Total & 150 & 150 & 300 \\
\hline & & & \\
\hline & 50 & 5 & 5 \\
\hline
\end{tabular}

Table 5: Data and result of test of significant difference in the mean age of Expired and Shift out patients

\begin{tabular}{|c|l|c|c|c|c|c|}
\hline \multirow{3}{*}{ AGE } & Outcome & $\mathbf{N}$ & Mean & Std. Deviation & t & Significance \\
\cline { 2 - 6 } & Expired & 150 & 64.00 & 14941 & 1.3 & \multirow{2}{*}{$\mathrm{P}>0.05$} \\
\cline { 2 - 6 } & Shift out & 150 & 58.00 & 16154 & 5 & \\
\hline
\end{tabular}

Above table shows that the obtained t value 1.3 5, p>0.05; that means there is no significant difference in the mean age of Expired and Shift out patients.

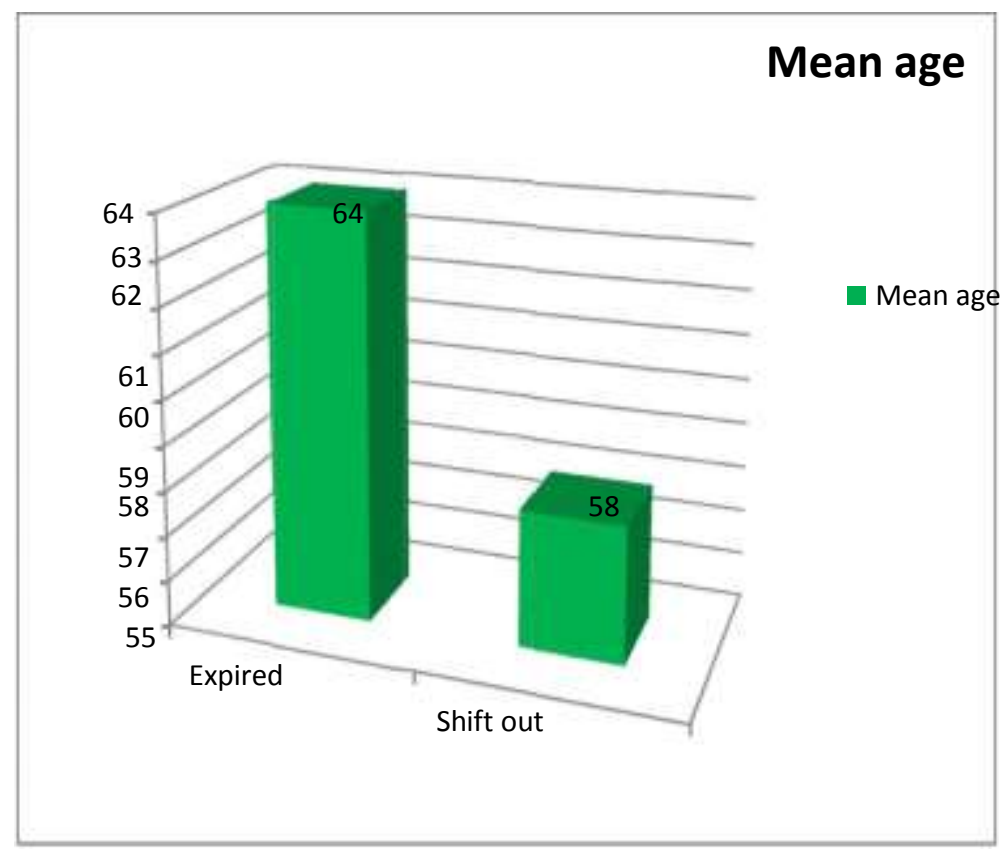

Figure 2: Mean age of Expired and Shift out patients 


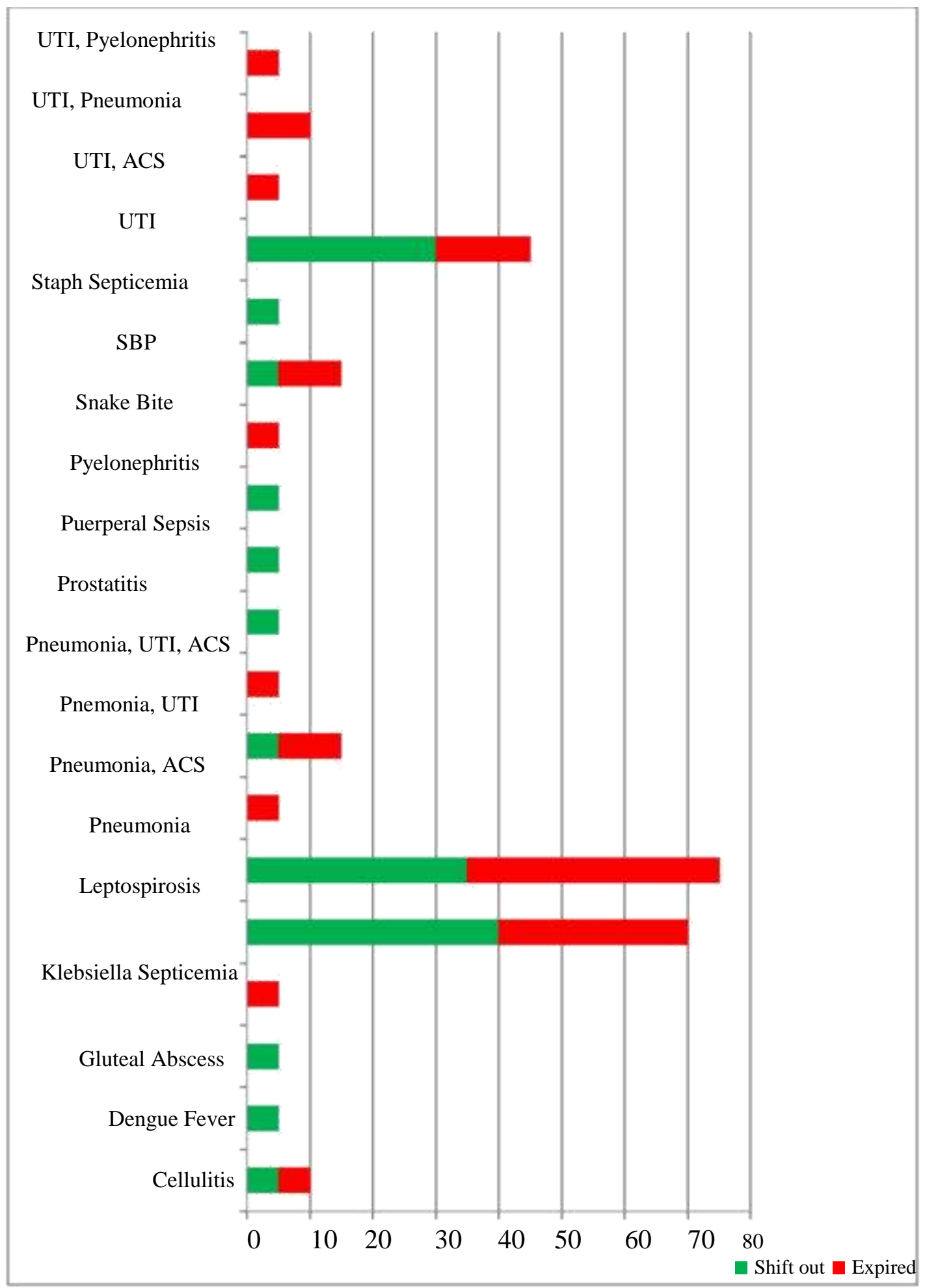

Figure 3: Outcomes and Diagnosis

The most common reason for admission was Pneumonia (110 patients) followed by Leptospirosis (70 patients).

Table 6: Data and result of test of significant difference in the mean MPV Day 1 between Expired and Shift out patients

\begin{tabular}{|c|c|c|c|c|l|c|}
\hline \multirow{4}{*}{ AGE } & Outcome & N & Mean & $\begin{array}{c}\text { Std. } \\
\text { Deviation }\end{array}$ & $\mathbf{t}$ & Significance \\
\cline { 2 - 7 } & Expired & 150 & 9.1986 & 1.5581 & \multirow{2}{*}{3.92} & $\mathrm{p}<0.01$ \\
\cline { 2 - 7 } & Shift out & 150 & 7.767 & 1.2537 & \\
\hline
\end{tabular}


Above table shows that the obtained $t$ value 3.92 is greater than the critical value $2.58 ; \mathrm{p}<0.01$, that means there exists a significant difference in the MP V Day 1 between Expired and Shift out patients

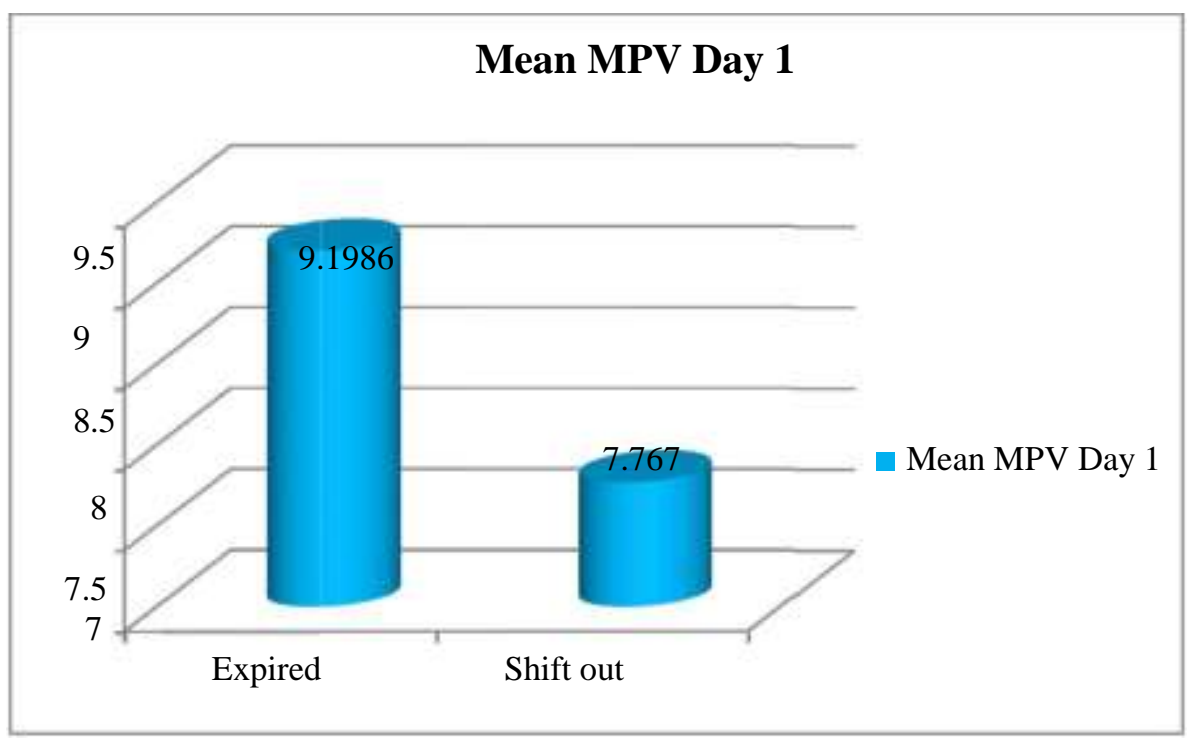

Figure 4: Mean MPV Day 1 of Expired and Shift out patients

Table 7: Data and result of test of significant difference in the mean of Highest MPV between Expired and Shift out patients

\begin{tabular}{|c|c|c|c|c|l|c|}
\hline \multirow{2}{*}{ AGE } & Outcome & N & Mean & $\begin{array}{c}\text { Std. } \\
\text { Deviation }\end{array}$ & t & Significance \\
\cline { 2 - 7 } & Expired & 15 & 0 & 9.713 & \multirow{2}{*}{4.37} & $\mathrm{p}:<0.01$ \\
\cline { 2 - 7 } & Shift out & 15 & 0 & 8.171 & \\
\hline
\end{tabular}

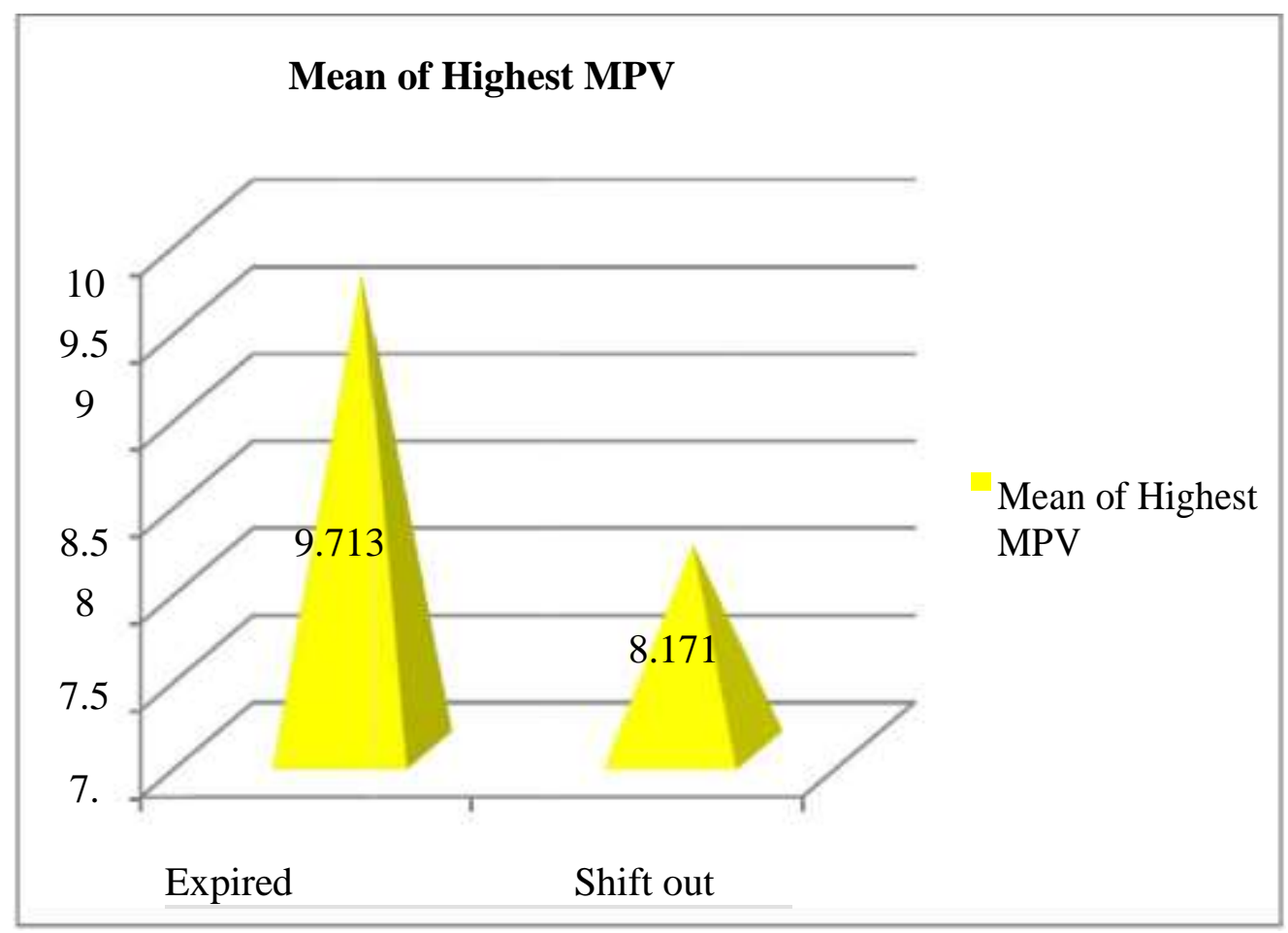

Fig.-5-Mean of the Highest MPV of expired and shiftout patient 


\section{References}

1. Members of the American College of Chest Physicians/Society of Critical Care Medicine Consensus Conference (1992) Definitions for sepsis and organ failure and guidelines for the use of innovative therapies in sepsis. Crit Care Med 20:864874

2. Rangel-Frausto MS, Pittet D, Costigan M, Hwang T, Davis CS, Wenzel RP (1995) The natural history of the systemic inflammatory response syndrome (SIRS). A prospective study. JAMA 273:117-123

3. Li ZQ, Liu W, Park KS, et al. Defining a second epitope for heparin-induced thrombocytopenia/thrombosis antibodies using KKO, a murine HIT-like monoclonal antibody. Blood. 2002;99:1230-1236.

4. Theodore E. Warkentin, William C. Aird, and Jacob H. Rand. Platelet-Endothelial Interactions: Sepsis, HIT, and Antiphospholipid Syndrome. American Society of Hematolgy 2003.

5. Gabay C, Kushner I (1999) Acute- phase proteins and other systemic responses to inflammation. N Engl J Med 340:448-454

6. Baughman RP, Lower EE, Flessa HC, et al. Thrombocyto-penia in the intensive care unit. Chest 1993; 104:1243-1247

7. Kinasewitz GT, Yan SB, Basson B, et al. Universal changes in biomarkers of coagulation and inflammation occur in patients with severe sepsis, regardless of causative micro-organism [ISRCTN74215569]. Crit Care 2004; 8:R82-R90

8. Vanderschueren S, De Weerdt A, Malbrain $\mathrm{M}$, et al. Thrombocytopenia and prognosis in intensive care. Crit Care Med 2000; 28:1871-1876

9. Stephan F, Hollande J, Richard O, et al. Thrombocytopenia in a surgical ICU. Chest 1999; 115:1363-1370

10. Nijsten MW, ten Duis HJ, Zijlstra JG, et al. Blunted rise in platelet count in critically ill patients is associated with worse outcome. Crit Care Med 2000; 28:3843-3846

11. Warkentin TE, Roberts RS, Hirsh J, et al. An improved definition of immune heparin-induced thrombocytopenia in postoperative orthopedic patients. Arch Intern Med 2003; 163:2518-2524

12. Warkentin TE, Levine MN, Hirsh J, et al. Heparin-induced thrombocytopenia in patients treated with low-molecularweight heparin or unfractionated heparin. N Engl J Med 1995; 332:1330-1335

13. Suh JS, Malik MI, Aster RH, Visentin GP. Characterization of the humoral immune response in heparin-induced thrombocytopenia. Am J Hematol. 1997;54:196-201.

14. Newman PM, Chong BH. Further characterization of antibody and antigen in heparin-induced thrombocytopenia. $\mathrm{Br} J$ Haematol. 1999;107:303-309.

15. Visentin GP, Moghaddam M, Beery SE, McFarland JG, Aster RH. Heparin is not required for detection of antibodies associated with heparin-induced thrombocytopenia/thrombosis. J Lab Clin Med. 2001;138:22-31.

16. Warkentin TE, Kelton JG. Delayed-onset heparin-induced thrombocytopenia and thrombosis. Ann Intern Med. 2001;135:502-506.

17. Warkentin TE, Bernstein RA. Delayedonset heparin-induced thrombocytopenia and cerebral thrombosis after a single administration of unfractionated heparin. N Engl J Med. 2003;348:1067-1069.

18. Warkentin TE, Kelton JG. Temporal aspects of heparin- induced thrombocytopenia. $N$ Engl $J$ Med. 2001;344:1286- 1292.

19. Kamath S, Blann AD, Lip GY. Platelet activation: assessment and quantification. Eur Heart J 2001; 22: 1561-71. 
20. Thompson CB, Love DG, Quinn PG, Valeri CR. Platelet size does not correlate with platelet age. Blood 1983; 62: 487-94.

21. Thompson CB, Jakubowski JA. The pathophysiology and clinical relevance of platelet heterogeneity. Blood 1988; 72: 18.

22. Kaushansky K. The molecular mechanisms that control thrombopoiesis. $J$ Clin Invest 2005; 115: 3339-47.

23. Butkiewicz AM, Kemona H, DymickaPiekarska V, Matowicka- Karna J, Radziwon P, Lipska A. Platelet count, mean platelet volume and thrombocytopoietic indices in healthy women and men. Thromb Res 2006; 118: 199-204

24. Miyazaki H, Kato T. Thrombopoietin: biology and clinical potentials. Int $J$ Hematol 1999; 70: 216-25.

25. hompson CB. From precursor to product: how do megakaryocytes produce platelets? Prog Clin Biol Res 1986; 215: 361-71.

26. Schwertz H, Köster S, Kahr WH, et al. Anucleate platelets generate progeny. Blood 2010; 115: 3801-9.

27. Yilmaz MB, Saricam E, Biyikoglu SF, et al. Mean platelet volume and exercise stress test. J Thromb Thrombolysis 2004; 17: 115-20.

28. Bakovic D, Pivac N, Eterovic D, et al. Changes in platelet size and spleen volume in response to selective and non-selective beta- adrenoceptor blockade in hypertensive patients. Clin Exp Pharmacol Physiol 2009; 36:441-6.

29. Jagroop IA, Clatworthy I, Lewin J, Mikhailidis DP. Shape change in human platelets: measurement with a channelyzer and visualisation by electron microscopy. Platelets 2000; 11: 28-32.

30. Turner-Stokes L, Jones D, Patterson KG, Todd-Pokropek A, Isenberg DA, Goldstone AH. Measurement of haematological indices of chronic rheumatic disease with two newer generation auto- mated systems, the $\mathrm{H} 1$ and H6000 (Technicon). Ann Rheum Dis 1991; 50: 583-7.

31. Boos CJ, Balakrishnan B, Lip GY. The effects of coronary artery disease severity on time-dependent changes in platelet activation indices in stored whole blood. $J$ Thromb Thrombolysis 2008; 25: 135-40.

32. McShine RL, Sibinga S, Brozovic B. Differences between the effects of EDTA and citrate anticoagulants on platelet count and mean platelet volume. Clin Lab Haematol 1990; 12: 277-85.

33. Dastjerdi MS, Emami T, Najafian A, Amini M. Mean platelet volume measurement, EDTA or citrate? Hematology 2006; 11: 317-9.

34. Bath PM. The routine measurement of platelet size using sodium citrate alone as the anticoagulant. Thromb Haemost 1993; 70: 687- 90 .

35. Diaz-Ricart M, Brunso L, Pino M, Navalon F, et al. Preanalytical treatment of EDTA-anticoagulated blood to ensure stabilization of the mean platelet volume and component measured with the ADVIA counters. Thromb Res 2010; 126: e30-5.

36. Beyan C, Kaptan K, Ifran A. Platelet count, mean platelet volume, platelet distribution width, and plateletcrit do not correlate with optical platelet aggregation responses in healthy volunteers. J Thromb Thrombolysis 2006; 22: 161-4.

37. Ozdemir O, Soylu M, Alyan O, et al. Association between mean platelet volume and autonomic nervous system functions: Increased mean platelet volume reflects sympathetic overactivity. Exp Clin Cardiol 2004; 9: 243-7.

38. Vagdatli E, Gounari E, Lazaridou E, Katsibourlia E, Tsikopoulou F, Labrianou I. Platelet distribution width: a simple, practical and specific marker of activation of coagulation. Hippokratia 2010; 14: 2832. 
39. Cooke J, Murphy T, McFadden E, O'Reilly M, Cahill MR. Can mean platelet component be used as an index of platelet activity in stable coronary artery disease? Hematology 2009; 14: 111-4.

40. Babu E, Basu D. Platelet large cell ratio in the differential diagnosis of abnormal platelet counts. Ind J Pathol Microbiol 2004; 47: 202-5.

41. Zampieri et al. An Increase in Mean Platelet Volume after admission is associated with higher mortality in critically ill patients. Annals of Intensive Care 2014, 4:20

42. Eberhardt A, et al. 15th International Congress on Infectious Disease. Bangkok, Thailand; June 13-16, 2012. Abstract No. 45.021

43. Becchi C, et al.. Department of Medical and Surgical Critical Care, Section of Anaesthesia and Intensive Care, University of Florence, Florence, Italy. Minerva Anestesiol. 2006 Sep;72(9):749-56.

44. Gunembakmaz et.al. Mean platelet volume predicts Embolic complication in Infective Endocarditis. International Journal of Infectious Diseases 2010 e982-e985

45. Huseyin Narci, Emin Turk , Erdal Karagulle et al. Baskent University Faculty of Medicine, Ankara, Turkey. The Role of Mean Platelet Volume in the Diagnosis of Acute Appendicitis: A Retrospective Case-Controlled Study. Iran Red Crescent Med J. 2013 December; 15(12) 